Imágenes en Medicina Intensiva

\title{
Aneurisma y úlceras penetrantes de aorta torácica
}

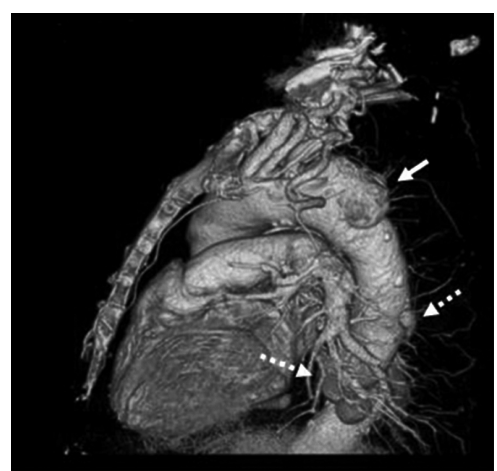

Figura 1.

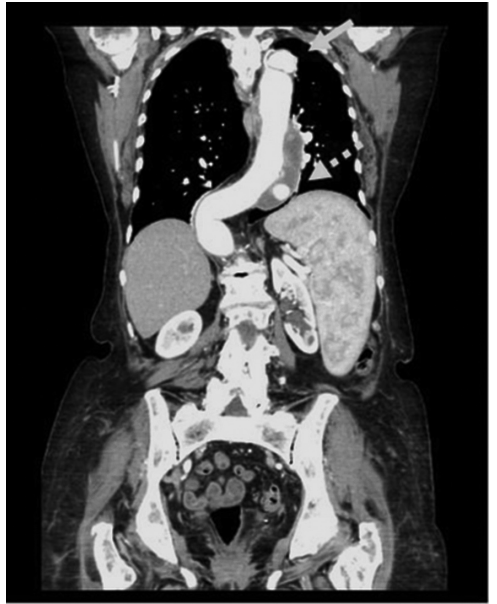

Figura 2 .

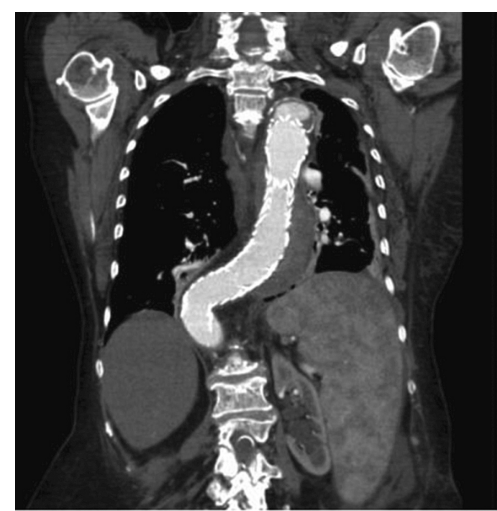

Figura 3.

Paciente de 80 años que ingresa en la UVI en postoperatorio electivo de aneurisma aórtico. En las pruebas de imagen preoperatorias se visualizan tres lesiones (figs. 1 y 2): aneurisma en el cayado aórtico con pared calcificada, trombo mural y pequeña úlcera penetrante, por detrás de la salida de la arteria subclavia izquierda (flecha continua). En la aorta elongada, de aproximadamente $5 \mathrm{~cm}$ de diámetro en su porción torácica descendente, se observan dos úlceras penetrantes con rotura contenida de aorta descendente y hematoma intramural a 6 y $11 \mathrm{~cm}$ (flecha discontinua). Se colocó endoprótesis aórtica distal a la arteria carótida común englobando de manera parcial la úlcera aórtica penetrante más distal, quedando un leak intraaórtico proximal (fig. 3) pendiente de reintervención. El postoperatorio cursó sin incidencias y se pudo ingresarlo en planta en menos de $24 \mathrm{~h}$.

ISMAEL LÓPEZ DE TORO MARTÍN CONSUEGRA, VICTORIA ANDREA HORTÍGÜELA MARTÍN 